\title{
Study protocol to investigate the effect of a lifestyle intervention on body weight, psychological health status and risk factors associated with disease recurrence in women recovering from breast cancer treatment [ISRCTN0804523 I]
}

\author{
John M Saxton*1, Amanda Daley², Nicola Woodroofe ${ }^{3}$, Robert Coleman ${ }^{4}$, \\ Hilary Powers ${ }^{5}$, Nanette Mutrie ${ }^{6}$, Vanessa Siddall ${ }^{4}$ and Helen Crank ${ }^{1}$
}

Address: ${ }^{1}$ Centre for Sport and Exercise Science, Sheffield Hallam University, Sheffield, UK, ${ }^{2}$ Department of Primary Care and General Practice, University of Birmingham, UK, ${ }^{3}$ Biomedical Research Centre, Sheffield Hallam University, Sheffield, UK, ${ }^{4}$ Academic Unit of Clinical Oncology, University of Sheffield, Weston Park Hospital, Sheffield, UK, ${ }^{5}$ Centre for Human Nutrition, University of Sheffield, UK and ${ }^{6}$ Department of Sport, Culture and the Arts, Strathclyde University (Jordanhill Campus), Glasgow, UK

Email: John M Saxton* - j.m.saxton@shu.ac.uk; Amanda Daley - a.daley@bham.ac.uk; Nicola Woodroofe -n.woodroofe@shu.ac.uk; Robert Coleman - r.e.coleman@sheffield.ac.uk; Hilary Powers - h.j.powers@sheffield.ac.uk; Nanette Mutrie - nanette.mutrie@strath.ac.uk; Vanessa Siddall - Vanessa.Siddall@nottingham.ac.uk; Helen Crank - h.crank@shu.ac.uk

* Corresponding author

Published: 09 February 2006

BMC Cancer 2006, 6:35 doi:10.1/86/147/-2407-6-35
Received: 31 October 2005

Accepted: 09 February 2006

This article is available from: http://www.biomedcentral.com/I47I-2407/6/35

(C) 2006 Saxton et al; licensee BioMed Central Ltd.

This is an Open Access article distributed under the terms of the Creative Commons Attribution License (http://creativecommons.org/licenses/by/2.0), which permits unrestricted use, distribution, and reproduction in any medium, provided the original work is properly cited.

\begin{abstract}
Background: Breast cancer survivors often encounter physiological and psychological problems related to their diagnosis and treatment that can influence long-term prognosis. The aim of this research is to investigate the effects of a lifestyle intervention on body weight and psychological well-being in women recovering from breast cancer treatment, and to determine the relationship between changes in these variables and biomarkers associated with disease recurrence and survival.
\end{abstract}

Methods/design: Following ethical approval, a total of 100 patients will be randomly assigned to a lifestyle intervention (incorporating dietary energy restriction in conjunction with aerobic exercise training) or normal care control group. Patients randomised to the dietary and exercise intervention will be given individualised healthy eating dietary advice and written information and attend moderate intensity aerobic exercise sessions on three to five days per week for a period of 24 weeks. The aim of this strategy is to induce a steady weight loss of up to $0.5 \mathrm{Kg}$ each week. In addition, the overall quality of the diet will be examined with a view to (i) reducing the dietary intake of fat to $\sim 25 \%$ of the total calories, (ii) eating at least 5 portions of fruit and vegetables a day, (iii) increasing the intake of fibre and reducing refined carbohydrates, and (iv) taking moderate amounts of alcohol. Outcome measures will include body weight and body composition, psychological health status (stress and depression), cardiorespiratory fitness and quality of life. In addition, biomarkers associated with disease recurrence, including stress hormones, estrogen status, inflammatory markers and indices of innate and adaptive immune function will be monitored.

Discussion: This research will provide valuable information on the effectiveness of a practical, easily implemented lifestyle intervention for evoking positive effects on body weight and psychological well-being, two important factors that can influence long-term prognosis in breast cancer survivors. However, the added value of the study is that it will also evaluate the effects of the lifestyle intervention on a range of biomarkers associated with disease recurrence and survival. Considered together, the results should improve our understanding of the potential role that lifestyle-modifiable factors could play in saving or prolonging lives. 


\section{Background}

Although the number of women who survive breast cancer is increasing, survivors often encounter physiological and psychological problems related to their diagnosis and treatment that can influence long-term prognosis. A gain in body weight [1-6] and psychosocial distress [7-12] are two commonly encountered adverse responses to breast cancer diagnosis and treatment that can have a negative impact on quality of life and survival. Lifestyle strategies that can attenuate the negative effects of such physical and mental health outcomes after breast cancer diagnosis could further improve the quality of life and long-term prognosis of breast cancer survivors.

Up to $60 \%$ of women diagnosed with breast cancer experience an increase in body weight associated with chemotherapy and treatment-related menopause [6] and there is evidence that heavier women and women who gain weight after diagnosis have an increased risk of disease recurrence and death compared to normal weight women [1-5]. Women with a high body mass index (BMI) have double the risk of 5-year recurrence and a $60 \%$ increased risk of death over 10 years in comparison to normalweight women [5]. Poorer survival in heavier patients could be due to higher levels of tumor-promoting hormones, consequent to an increased adiposity [13]. There is evidence that elevated estrogen levels influence the risk of breast cancer in postmenopausal women [14-16] and it was recently shown that overweight postmenopausal breast cancer patients have higher estrogen and testosterone levels than normal-weight patients [13]. This led to the suggestion that circulating estrogen levels could be a useful biomarker for weight loss intervention studies [13].

Following breast cancer diagnosis or treatment, four in ten women also experience high levels of emotional distress, including depression and anxiety [7], which persists for prolonged periods of time, irrespective of the treatment outcome [8-12]. Studies have shown that psychosocial stressors such as depression, anxiety and emotional distress are associated with impaired immune function [17], and this could have a direct impact on cancer outcomes $[18,19]$ and influence the risk of disease re-occurrence and death [20]. The adverse effect of psychosocial stressors on immune function is considered to be mediated by excess secretion of the stress hormone cortisol and the catecholamines $[21,22]$. Elevated cortisol and catecholamine levels evoked by psychological stressors can significantly influence immune function, including lymphocyte proliferation and natural killer (NK) cell activity [23-26]. Selfreported negative mood states have been associated with lower NK cell activity $[27,28]$ and symptoms of depression have been linked with increased salivary cortisol [29] impaired lymphocyte proliferation [30,31] and reduced NK cell cytotoxicity against tumor cells [32-34]. In addi- tion, studies have reported abnormal circadian rhythmicity of cortisol in breast cancer patients [35-39] and flattened or abnormal diurnal salivary cortisol rhythms have recently been associated with earlier mortality in breast cancer patients [38] and persistent fatigue in survivors 1-5 years after initial diagnosis [40].

Dietary energy restriction can reduce body weight and induce a positive effect on psychological well being in obese women and breast cancer survivors [41-44]. Weight loss interventions that reduce dietary intake of fat to 18$25 \%$ of the total calories can also evoke a significant reduction in serum estrogen levels in pre and postmenopausal women [45]. The positive effects of dietary energy restriction on these physical and emotional sequelae might be augmented by the implementation of adjunctive exercise therapy $[46,47]$. Regular physical activity can help to control body weight and is known to reduce the risk of breast cancer [48-53]. Recent evidence also suggests that it can halve the risk of death in breast cancer patients [54]. The precise mechanisms underpinning the positive effects of physical activity on breast cancer risk and survival are unknown, although physical activity has been associated with a lower concentration of circulating estrogen in some studies $[55,56]$, as well as lower circulating levels of the inflammatory mediators, C-reactive protein (CRP) [5759] and interleukin-6 (IL-6) [60,61]. Increased CRP levels are observed in overweight individuals $[62,63]$ and have been linked with increased cancer risk [64,65] and elevated levels of cortisol in individuals subjected to psychological stress [66]. Depression enhances the production of IL-6 [67-69] and this proinflammatory cytokine is also secreted from adipocytes in proportion to body fat mass [60]. IL-6 induces CRP synthesis in the liver and can indirectly raise cortisol levels via stimulation of corticotropinreleasing hormone production [67]. Elevated estrogen levels may also increase CRP levels through a non-inflammatory mechanism [70].

Regular physical activity can also have a positive effect on psychological health status $[71,72]$ and quality of life [73] in breast cancer survivors that could enhance immune function through normalisation of stress hormone levels. Although there is evidence for decreased cortisol levels $[74,75]$ and changes in immune cell numbers and function after psychosocial interventions in breast cancer patients $[76,77]$, only three studies have investigated the effects of exercise therapy on immune function in breast cancer survivors. Peters et al. $[78,79]$ reported an increase in the percentage of NK cells and an improvement in NK cell function and monocyte phagocytic capacity that was accompanied by an increase in 'satisfaction of life' score after seven months of moderate exercise training, whereas Nieman et al. [80] did not observe any change in NK cell function following a shorter period of training. The latter 
study had only six subjects in the experimental (exercise therapy) group, and neither study measured stress hormone levels in patients. In a more recent study, Fairey et al. [81] showed that a 15 week programme of aerobic exercise training improved NK cell cytotoxic activity and peripheral blood lymphocyte function in postmenopausal breast cancer survivors. In sedentary, healthy individuals, regular moderate aerobic exercise has been shown to boost NK cell function [82] and decrease the incidence of upper respiratory tract infections in previously sedentary individuals [82-84]. In elderly females however, evidence for an improvement in immune cell function with aerobic exercise training is inconclusive, although highly trained elderly females exhibit superior resting NK cell function and $\mathrm{T}$ cell proliferation responses compared to agematched sedentary controls [83]. The lack of intervention studies incorporating biomarkers of immune function in women recovering from breast cancer treatment is surprising, as restoration of lymphocyte and NK cell function after treatment is predictive of survival $[28,85,86]$ and is independent of stage of disease and adjunctive treatment approach [86]. This suggests that lifestyle interventions which could have an impact on immune function are worth exploring, as they could have a significant influence on disease-free survival in breast cancer patients.

Previous studies have investigated the feasibility and efficacy of lifestyle interventions in breast cancer patients and obese women, in terms of recruitment, compliance and weight loss $[42,43,87,88]$. Some studies have also examined the effects of lifestyle interventions on aspects of psychological $[41,47,71,72]$ and physiological $[42,87,88]$ well-being. However, no previous studies have investigated the effects of a dietary and exercise intervention on a range of important prognostic breast cancer biomarkers that could be strongly influenced by weight loss and improved psychological well-being. Thus, the aim of the intended research is to examine the effects of a dietary and exercise intervention on body weight, indices of psychological well-being and biomarkers associated with disease recurrence and physiological health status in female breast cancer survivors. We hypothesize that the lifestyle intervention will evoke a reduction in body weight and an improvement in psychological well-being. Secondly, that improvements in blood markers of cancer risk and physiological health status (estrogen, CRP, IL-6), psychosocial stress (cortisol and catecholamines) and immune function (lymphocyte proliferation and NK cell function) will be associated with changes in body weight and psychological well-being induced by the lifestyle intervention. Considered together, the results of this study would provide valuable new information to improve our understanding of the role that lifestyle-modifiable factors can play in saving or prolonging the lives of women who have been treated for breast cancer.

\section{Research design and methods Overall aim of the study}

To examine the effects of a practical lifestyle intervention that could be easily implemented by overweight or obese women $(\mathrm{BMI}>25)$ who have undergone breast cancer treatment, on body weight, indices of psychological wellbeing, biomarkers associated with disease recurrence and physiological health status and quality of life.

\section{Primary aims}

1. To examine the effects of a dietary and exercise intervention on body weight and body composition in overweight or obese women who have undergone breast cancer treatment.

2. To examine the effects of a dietary and exercise intervention on indices of psychological health status and biomarkers associated with disease recurrence in overweight or obese women who have undergone breast cancer treatment.

\section{Secondary aims}

1. To examine the relationship between change in body weight and biomarkers associated with disease recurrence and physiological health status, including circulating levels of estrogen, CRP and IL-6.

2. To examine the relationship between changes psychological health status, circulating stress hormones and indices of immune function.

3. To examine the effects of the dietary and exercise intervention on broader quality of life dimensions.

\section{Patient recruitment}

A total of 100 women (BMI > 25) who have undergone appropriate treatment for operable breast cancer within the past 3-18 months and are no longer undergoing chemotherapy or radiation therapy, will be recruited from the Cancer Research Centre, Weston Park Hospital, Sheffield University Hospitals NHS Trust. The incidence of breast cancer within the North Trent Regional Health Authority area is relatively high, with 850 cases per year and, on the basis of current rates of breast cancer survival in South Yorkshire and recruitment rate in our ongoing trial, we expect to recruit patients at the rate of approximately six per month for 16 months. Ethical approval has been obtained from the South Sheffield Research Ethics Committee and informed consent will be obtained from all participants before they enter the study.

\section{Randomisation}

The minimisation technique [89] will be used to allocate the patients into one of two groups (i) lifestyle intervention group, incorporating moderate dietary energy restric- 
tion of $600 \mathrm{kcal}$ per day in conjunction with aerobic exercise training on 3-5 days per week, or (ii) normal care control group. Minimisation will be used to balance the potentially confounding variables of chemotherapy and treatment with Tamoxifen, aromatase inhibitors or no hormone therapy across the groups. Randomisation will be performed by an independent researcher at the Clinical Trials Research Unit, University of Leeds. The intervention will last for 24 weeks, with outcome measures being assessed in the week before and the week after the intervention period and at the mid-intervention time point of 12 weeks. Patients would be recruited over 16 months, ensuring completion of the trial by 22 months and reporting of the data by 24 months.

\section{Details of power calculations and sample size}

Body weight was chosen as the primary outcome variable for calculation of sample size. Utter et al. [88] reported a $8.1 \mathrm{~kg}$ reduction in body weight in obese women following a 12 week lifestyle intervention, incorporating moderate dietary energy restriction in conjunction with exercise. Body weight changed from a baseline \pm SD level of $89.9 \pm$ 11.7 to $81.8 \pm 10.8 \mathrm{~kg}$ following the intervention. This amount of weight loss is associated with improved physical and psychological health in obese women $[41,90]$. On the basis of these data, and taking into account an expected patient drop-out of up to $10 \%$ (based on the drop-out rate in our ongoing trial with breast cancer survivors [91]), recruitment of 50 patients for each group will give us $90 \%$ power to detect a difference in body weight of $8 \mathrm{~kg}$ at the $\alpha$ level of 0.05 .

\section{Patient inclusion criteria}

a. Postmenopausal women (confirmed by plasma estradiol and gonadotrophin measures in all women aged $<55$ ) with a BMI $>25$ and classified as disease stage I-III. In our experience [91], a high proportion of breast cancer patients $(>80 \%)$ meet the BMI criteria and would be suitable for participation in the study.

b. Patients must have completed some form of breast cancer treatment at least three months, and not more than 18 months ago.

c. Patients on Tamoxifen and other endocrine treatments but not hormone replacement therapy (HRT) will be included.

d. Patients must be willing and able to attend supervised exercise sessions at least 3 times per week for a period of 24 weeks, with the intention of achieving an $80 \%$ minimum compliance target for attendance. e. Patients must be an exercise pre-contemplator, contemplator or preparer as defined by the Transtheoretical Model [92].

\section{Patient exclusion criteria}

a. Metastatic breast cancer patients and patients with inoperable or active loco-regional disease.

b. Patients following alternative/complementary diets or taking high dose antioxidant supplements.

c. Patients with a physical/psychiatric impairment that would seriously impair their physical mobility.

d. Patients who are currently suffering from severe nausea, anorexia or other diseases affecting health (e.g. arthritis and multiple sclerosis).

e. HRT is not commonly prescribed in women who are recovering from breast cancer treatment, but use of HRT or oral contraceptives within the past four months is an exclusion criteria.

f. Patients who are currently engaged in exercise (two or more times per week for at least $30 \mathrm{~min}$ per session during the previous 3 months).

\section{Supervised exercise}

Patients randomised to the dietary and exercise intervention will attend moderate intensity aerobic exercise sessions on three to five days per week for a period of 24 weeks under the supervision of an exercise scientist. To account for differences in daily patterns of fatigue and to minimise attrition, patients will be offered different times to chose from including week-ends. Patients will be encouraged to attend five supervised sessions each week, and must try to attend at least three of the sessions. Patients not able to attend five supervised sessions will be counselled on how they can fit an extra 1-2 home/community-based exercise sessions into their weekly routine. All sessions of physical activity will be recorded in a physical activity log and portable pedometers (Omron Healthcare, UK) will be used to determine the number of steps/ distance walked each day. Supervised exercise will be performed in groups of up to eight participants in an exercise room that contains a variety of aerobic exercise equipment. Each session will comprise a 10 minute warm-up period (involving light aerobic exercise and gentle range of motion exercises), $30 \mathrm{~min}$ of aerobic exercise at an intensity of $70 \%-85 \%$ heart rate reserve, and a $10 \mathrm{~min}$ cool-down period involving lower intensity aerobic exercise and some light stretching. Patients will wear heart rate monitors throughout the exercise sessions and heart rate and ratings of perceived exertion [93] will be assessed at regular intervals. In accordance with the recommenda- 
tions of Biddle et al. [94], patients will be offered a range of aerobic exercise modalities at these sessions (e.g. stepping, cycling, \& walking/jogging) to promote enjoyment and to aid compliance to the programme. Patients will be encouraged to use their preferred exercise mode to strengthen the possibility of them maintaining a physically active lifestyle when the supervised exercise programme has been completed. The exercise therapy sessions will use a variety of cognitive-behavioural techniques for promoting exercise adherence as well as positive attitudes and experiences.

\section{Dietary energy restriction}

Patients randomised to the dietary and exercise intervention will be given individualised healthy eating dietary advice and written information: 'Weight Loss On A Plate' (Scottish Dietetic Association). The focus of the verbal advice will be on reducing the patient's total daily calorie intake to $600 \mathrm{kcal}$ below their calculated energy requirements. Individual energy requirements will be estimated from formulae of basal metabolic rate and physical activity level (Scottish Dietetic Association). The aim of this strategy is to induce a steady weight loss of up to $0.5 \mathrm{Kg}$ each week. In addition, the overall quality of the diet will be examined with a view to (i) reducing the dietary intake of fat to $\sim 25 \%$ of the total calories, (ii) eating at least 5 portions of fruit and vegetables a day, (iii) increasing the intake of fibre and reducing refined carbohydrates, and (iv) taking moderate amounts of alcohol. Patients will be required to complete a 3 day diet diary pre intervention and then weekly throughout the study. The diary will include one day from the weekend. The diaries from pre intervention and from weeks 6, 12, 18 and 24 will be analysed, looking specifically at macronutrients, using Dietmaster software (SDA Solutions, London, UK) computer dietary analysis package. Once a week, patients will meet with the research assistant who will discuss their individual diet diaries with them and identify ways which they can further improve their nutritional intake. Patients in the control group will be provided with a general healthy eating booklet 'Getting the Balance Right' (British Nutrition Foundation).

\section{Outcome measures}

The intervention will last for 24 weeks, with all outcome variables being assessed in the week before and the week after the intervention period unless otherwise stated.

\section{Primary outcome measure}

Body weight and body composition

Patients will be weighed to the nearest $0.05 \mathrm{~kg}$ and percentage body fat estimated using bio-electrical impedance (Bodystat 1500, Bodystat Ltd., UK). Waist and hip girths will be measured to the nearest $0.5 \mathrm{~cm}$ using an inelastic circumference tape. Body weight will be measured at weekly intervals in the intervention group, whereas bioelectrical impedance analysis and girth measurements will only be performed in the week before and after the intervention period and at the mid-intervention time point of 12 weeks.

\section{Other outcome measures}

Psychological indices, cardiorespiratory fitness and quality of life Psychological stress

Psychological stress will be assessed using the Perceived Stress Scale (PSS) [95]. The PSS is one of the most widely used psychological instrument for measuring the perception of stress. It measures the degree to which situations in an individual's life are appraised as stressful. The items evaluate how unpredictable, uncontrollable, and overloaded respondents find their lives. The scale also includes a number of direct queries about current levels of experienced stress. Psychological stress will be assessed in the week before and after the intervention period and at the mid-intervention time point of 12 weeks.

\section{Depression}

Depression will be assessed using the Beck Depression Inventory II (BDI-II) [96]. The BDI is a 21-item test which measures the presence and degree of depression in respondents. It assesses specific symptoms or attitudes which appear to be specific to depressed patients, and which are consistent with descriptions of the depression contained in the psychiatric literature. Depression will be assessed in the week before and after the intervention period and at the mid-intervention time point of 12 weeks.

\section{Cardiorespiratory fitness}

Cardiorespiratory fitness will be assessed using a singlestage submaximal treadmill walking test [97]. Improved cardiorespiratory fitness in breast cancer patients following a 16 week exercise intervention has previously been demonstrated using this treadmill test [98]. This test is also being used successfully in our laboratory to assess physiological adaptations resulting from exercise therapy in an ongoing breast cancer trial [91].

\section{Quality of life}

The Functional Assessment of Cancer Therapy-General (FACT-G) and (FACT-B) [99] will be used to assess quality of life. Quality of life is an important clinical outcome and the FACT-G and FACT-B collectively measure five aspects of quality of life: physical, functional, emotional, social and additional concerns specific to breast cancer. Quality of life will be assessed in the week before and after the intervention period and at the mid-intervention time point of 12 weeks. 


\section{Physical activity behaviour}

Physical activity behaviour at the baseline, and at weeks $6,12,18$ and 24 will be assessed using the Stanford SevenDay Physical Activity Recall (PAR) [100], which has been used successfully in a number of studies. This will be administered by telephone in the control patients.

\section{Biomarkers associated with disease recurrence and physiological health status \\ Blood sampling}

Blood samples will be drawn from an antecubital vein between 8:30-10 a.m. in the morning, following a 12 hour overnight fast. Blood will be collected into Vacutainer tubes (BD Biosciences Ltd, Oxford, U.K.), containing EDTA for leukocyte counts, plasma biomarker and immune function analysis. NK cells and T lymphocytes will be isolated from whole blood within $2 \mathrm{~h}$ of venepuncture for analysis of NK Cell and T cell function. Plasma samples will be stored at $-80^{\circ} \mathrm{C}$ for batch-analysis at a later date. All flow cytometric analyses, leukocyte functional assays and enzyme immunoassays will be performed in the Biomedical Sciences Research Centre, Sheffield Hallam University, under the supervision of one of the key personnel, Professor Nicola Woodroofe.

\section{Estrogen, stress hormones and inflammatory markers}

Plasma IL-6, epinephrine and norepinephrine levels will be measured using commercially available enzyme-linked immunoassays (ELISA) kits (Bio-Quant Inc and Immunobiological Laboratories, Hamburg, R \& D Systems UK) and plasma hs-CRP will be measured by the Immunology Department, Northern General Hospital, Sheffield using a turbidimetric assay. Serum estradiol, estrone and estrone sulphate will be measured using high-sensitivity ELISA kits Bio-Quant Inc., CA, USA and Diagnostic Systems Laboratories Inc., OBI-DSL, Oxon, UK). Salivary cortisol levels will be measured on each of three consecutive days at 0800, 1200, 1700 and 2100 hours and the slope of diurnal cortisol variation will be determined from the pooled saliva samples at each daily time point using a regression of the log-transformed cortisol concentrations on sample collection time [38]. Easy-Reach Radio Pagers (British Telecommunications Plc, UK) will be used to signal saliva collection times and the importance of collecting samples at the designated times and recording the actual sample collection time will be emphasized. Saliva samples will be refrigerated, before collection within 2-4 days and frozen at $-70^{\circ} \mathrm{C}$ until analysis[40] using a high sensitivity salivary cortisol enzyme immunoassay (Salimetrics LLC, PA, USA).

\section{Differential leukocyte counts}

Differential leukocyte counts and other haematological parameters will be measured within 6 hours of blood sampling in the Department of Haematology, Royal Hal- lamshire Hospital (CPA accredited) using a Coulter STKS automated haematological analyser (Beckman Coulter U.K. Ltd, High Wycomb, U.K.) which is calibrated on a daily basis.

\section{Lymphocyte phenotyping}

The proportion of $\mathrm{NK}\left(\mathrm{CD} 3-\mathrm{CD} 16+\mathrm{CD} 56^{+}\right)$and $\mathrm{T}$ cell subsets $\left(\mathrm{CD}^{+}{ }^{+} \mathrm{CD} 4{ }^{+} ; \mathrm{CD}^{+}{ }^{+} \mathrm{CD} 8^{+}\right)$will be measured using whole blood multicolour flow cytometry. Whole blood will be collected into EDTA anticoagulant and $100 \mu \mathrm{l}$ aliquots incubated with appropriate combinations of fluorochrome (PE/FITC/PerCP)-conjugated monoclonal antibodies (mAb) to CD3, CD4, CD8, CD16 and CD56 using triple antibody sets (BD Biosciences Ltd). Lymphocyte and monocyte populations will be located on the basis of forward and side scatter and dead cells will be excluded. The proportion of cells expressing the given combination of antigens will be determined using a BD Biosciences FACSort ${ }^{\mathrm{TM}}$ flow cytometer and CELLQuest Pro $^{\mathrm{TM}}$ data acquisition and analysis software. Appropriate isotype matched, negative control antibodies will be included in all analyses.

\section{NK cell activity}

NK cell activity will be determined as the capacity of peripheral blood mononuclear cells to kill human erythroleukemia K562 target cells using flow cytometry, essentially as described previously [101]. Briefly, K562 cells in the log phase of growth will be harvested, washed and stained with the stable membrane dye PKH2 (BD Biosciences). Human peripheral blood mononuclear cells will be isolated by density gradient centrifugation on Ficoll (Sigma UK) and monocytes/macrophages will be removed by plastic adherence $\left(37^{\circ} \mathrm{C}, 1 \mathrm{~h}\right)$. Two-fold serial dilutions of effector cells $\left(800 \mu \mathrm{l}\right.$; starting at $\left.10^{6} \mathrm{cells} / \mathrm{ml}\right)$ will be placed in $12 \times 75 \mathrm{~mm}$ polystyrene tubes with 100 $\mu \mathrm{PKH} 2$ labelled target cells $\left(10^{5}\right.$ cells) to give a range of effector to target cell ratios (80:1 to $5: 1)$. Samples will be incubated at $37^{\circ} \mathrm{C}$ for $4 \mathrm{~h}$ after which time the DNA stain propidium iodide (which only stains non-viable cells) will be added. The proportion of $\mathrm{PKH}_{2}+\mathrm{PI}+$ (non-viable) K562 cells at each effector to target cell ratio will be determined after 15 min by flow cytometry. Appropriate controls (effector cells only; target cells only) will be included in all experiments.

\section{Lymphocyte proliferation assays}

Peripheral blood lymphocyte proliferative responses to recall antigen (purified protein derivative, PPD) will be determined. Peripheral blood mononuclear cells will be isolated as described above and $10^{5}$ cells incubated for 7 days $\left(37^{\circ} \mathrm{C}, 5 \% \mathrm{CO}_{2}\right)$ with an appropriate concentration of PPD $(\sim 1 \mu \mathrm{g} / \mathrm{ml})$ in 96-well microtitre plates. Antigen non-specific proliferation will be determined by incubating cells with plate-bound anti-CD3 mAb and soluble 
anti-CD28 mAb (both $10 \mu \mathrm{g} / \mathrm{ml}$ ) (BD Biosciences). For both assays, proliferation will be determined by preincubating cells with 5,6-carboxyfluorescein diacetate succimidyl ester (CFSE)(Molecular Probes) and subsequent measurement of the amount of dye per cell by flow cytometry [102].

\section{Data Analysis}

A mixed factorial ANOVA will be used to assess (i) changes from baseline on all outcome measures following the intervention within patient groups, and (ii) differences in outcome measures between patients in the lifestyle intervention and control groups post intervention. Pearson product moment correlation coefficients (r) will be calculated to determine bivariate relationships among changes in the variables. Statistical significance will be set at $p<0.05$. All data will be analysed using the SPSS statistical package (SPSS UK Ltd, Woking, U.K.).

\section{Competing interests}

The author(s) declare that they have no competing interests.

\section{Authors' contributions}

JS conceived and drafted the research proposal and sought funding for the study. He is responsible for overall project management. $\mathrm{AD}$ contributed to the study design and intervention in and has a role in collation of the psychological data and its analysis. RC contributed intellectual input to the research protocol and is involved with recruitment of volunteers and the provision of medical clearance for patients to participate in the study. NW provided expertise on the biomarker analysis and has a role in overlooking this work. HP provided valuable input to the design of the nutritional intervention and has a role in overlooking this component of the research. NM provided expertise on the quality of life outcomes and has a role in the analysis and interpretation of the quality of life data. VS advised on the practicalities of administering the dietary component of the intervention and has a role in overlooking this component of the research. HC contributed useful knowledge in relation to the exercise intervention and has a role in the hands-on delivery of the research.

\section{Acknowledgements}

This research is funded by a Project Grant from the American Institute for Cancer Research (Grant no. 05A008-REV).

\section{References}

I. Camoriano JK, Loprinzi CL, Ingle JN, Therneau TM, Krook JE, Veeder $\mathrm{MH}$ : Weight change in women treated with adjuvant therapy or observed following mastectomy for node-positive breast cancer. J Clin Oncol 1990, 8: I327-1334.

2. Chlebowski RT, Aiello E, McTiernan A: Weight loss in breast cancer patient management. J Clin Oncol 2002, 20: I I 28-I I 34.

3. Zumoff B, Gorzynski JG, Katz JL, Weiner H, Levin J, Holland J, et al.: Nonobesity at the time of mastectomy is highly predictive of 10-year disease-free survival in women with breast cancer. Anticancer Res 1982, 2:59-62.

4. Schapira DV, Kumar NB, Lyman GH, Cox CE: Obesity and body fat distribution and breast cancer prognosis. Cancer 199I, 67:523-528.

5. Goodwin PJ, Boyd NF: Body size and breast cancer prognosis: A critical review of the evidence. Breast Cancer Res Treat 1990, I 6:205-2|4.

6. Holmes MD, Kroenke $\mathrm{CH}$ : Beyond treatment: Lifestyle choices after breast cancer to enhance quality of life and survival. Womens Health Issues 2004, I 4: I I- I3.

7. Gallagher J, Parle M, Cairns D: Appraisal and psychological distress six months after diagnosis of breast cancer. $\mathrm{Br} J$ Heath Psych 2002, 7:365-376.

8. Epping-Jordan JE, Compas BE, Osowiecki DM, Oppedisano G, Gerhardt C, Primo K, et al:: Psychological adjustment in breast cancer: processes of emotional distress. Health Psychol 1999, I 8:315-326.

9. Maunsell E, Brisson J, Deschenes L: Psychological distress after initial treatment of breast cancer. Assessment of potential risk factors. Cancer 1992, 70:120-125.

10. Golden-Kreutz DM, Andersen BL: Depressive symptoms after breast cancer surgery: relationships with global, cancerrelated, and life event stress. Psycho-Oncology 2004, I 3:2 I I-220.

II. Kissane DW, Grabsch B, Love A, Clarke DM, Bloch S, Smith GC: Psychiatric disorder in women with early stage and advanced breast cancer: a comparative analysis. Aust NZJ Psychiatry 2004, 38:320-326.

12. Kornblith $A B$, Ligibel J: Psychosocial and sexual functioning of survivors of breast cancer. Semin Oncol 2003, 30:799-8I3.

13. McTiernan A, Rajan KB, Tworoger SS, Irwin M, Bernstein L, Baumgartner R, et al:: Adiposity and sex hormones in postmenopausal breast cancer patients. J Clin Oncol 2003, 21 : | 96 I- I 966.

14. Bernstein L, Ross RK: Endogenous hormones and breast cancer. Epidemiol Rev 1993, I 5:48-65.

15. Thomas HV, Reeves GK, Key TJ: Endogenous estrogen and postmenopausal breast cancer: a quantitative review. Cancer Causes Control 1997, 8:922-928.

16. Hankinson SE, Willett WC, Manson JE, Colditz GA, Hunter DJ, Spiegelman D, et al.: Plasma sex steroid hormone levels and risk of breast cancer in postmenopausal women. J Natl Cancer Inst 1998, 90:। $292-1299$.

17. Calabrese JR, Kling MA, Gold PW: Alterations in immunocompetence during stress, bereavement, and depression: focus on neuroendocrine regulation. Am | Psychiatry | 987, | 44: | | 23- | | 34.

18. Andersen BL, Kiecolt-Glaser JK, Glaser R: A biobehavioral model of cancer stress and disease course. Am Psychol 1994, 49:389-404.

19. Bovbjerg DH: Psychoneuroimmunology. Implications for oncology? Cancer 1991, 67:828-832.

20. Goodwin JS, Zhang DD, Ostir GV: Effect of depression on diagnosis, treatment, and survival of older women with breast cancer. J Am Geriatr Soc 2004, 52: I06-III.

21. McEwen BS, Stellar E: Stress and the individual. Mechanisms leading to disease. Arch Intern Med 1993, I 53:2093-210I.

22. Madden KS, Felten DL: Experimental basis for neural-immune interactions. Physiol Rev 1995, 75:77-106.

23. Banu N, Vaidya MP, Udupa KN: Alterations in circulating neurotransmitters \& cortisol with severity of breast cancer. Indian J Med Res 1988, 87:479-53.

24. Bryla CM: The relationship between stress and the development of breast cancer: a literature review. Oncol Nurs Forum 1996, 23:441-448.

25. Kronfol Z, Nair M, Zhang Q, Hill EE, Brown MB: Circadian immune measures in healthy volunteers: relationship to hypothalamic-pituitary-adrenal axis hormones and sympathetic neurotransmitters. Psychosom Med 1997, 59:42-50.

26. Benschop RJ, Nieuwenhuis EE, Tromp EA, Godaert GL, Ballieux RE, van Doornen LJ: Effects of beta-adrenergic blockade on immunologic and cardiovascular changes induced by mental stress. Circulation 1994, 89:762-769.

27. Levy S, Herberman R: Prognostic risk assessment in primary breast cancer by behavioural and immunological parameters. Health Psychol 1985, 4:99-II3.

28. Levy SM, Herberman RB, Lippman M, D'Angelo T, Lee J: Immunological and psychosocial predictors of disease recurrence in 
patients with early-stage breast cancer. Behav Med 199|, I 7:67-75.

29. Ehlert U, Patalla U, Kirschbaum C, Piedmont E, Hellhammer DH: Postpartum blues: salivary cortisol and psychological factors. J Psychosom Res 1990, 34:319-325.

30. Maes $M$ : Evidence for an immune response in major depression: a review and hypothesis. Prog Neuropsychopharmacol Biol Psychiatry 1995, 19:11-38.

31. Schleifer SJ, Keller SE, Meyerson AT, Raskin MJ, Davis KL, Stein M: Lymphocyte function in major depressive disorder. Arch Gen Psychiatry 1984, 41:484-486.

32. Caldwell CL, Irwin M, Lohr J: Reduced natural killer cell cytotoxicity in depression but not in schizophrenia. Biol Psychiatry 1991, 30: $1131-1138$

33. Maes M, Stevens W, Peeters D, DeClerck L, Scharpe S, Bridts C, et al: A study on the blunted natural killer cell activity in severely depressed patients. Life Sci 1992, 50:505-5I3.

34. Nerozzi D, Santoni A, Bersani G, Magnani A, Bressan A, Pasini A, et al.: Reduced natural killer cell activity in major depression: neuroendocrine implications. Psychoneuroendocrinology 1989 , | 4:295-30|.

35. Touitou Y, Levi F, Bogdan A, Benavides M, Bailleul F, Misset JL: Rhythm alteration in patients with metastatic breast cancer and poor prognostic factors. J Cancer Res Clin Oncol 1995, 121:181-188.

36. Touitou Y, Bogdan A, Levi F, Benavides M, Auzeby A: Disruption of the circadian patterns of serum cortisol in breast and ovarian cancer patients: relationships with tumour marker antigens. $\mathrm{Br} /$ Cancer 1996, 74: $\mid 248-1252$

37. van der Pompe G, Antoni MH, Heijnen CJ: Elevated basal cortisol levels and attenuated ACTH and cortisol responses to a behavioral challenge in women with metastatic breast cancer. Psychoneuroendocrinology 1996, 2 1:361-374.

38. Sephton SE, Sapolsky RM, Kraemer HC, Spiegel D: Diurnal cortisol rhythm as a predictor of breast cancer survival. J Natl Cancer Inst 2000, 92:994-1000.

39. Abercrombie HC, Giese-Davis ], Sephton S, Epel ES, Turner-Cobb JM, Spiegel D: Flattened cortisol rhythms in metastatic breast cancer patients. Psychoneuroendocrinology 2004, 29: 1082-1092.

40. Bower JE, Ganz PA, Dickerson SS, Petersen L, Aziz N, Fahey JL: Diur nal cortisol rhythm and fatigue in breast cancer survivors. Psychoneuroendocrinology 2005, 30:92-100.

4I. Kaukua J, Pekkarinen T, Mustajoki P: Health-related quality of life in obese outpatients losing weight with very-low-energy diet and behavioural modification: a 2 year follow-up study. Int Obes Relat Metab Disord 2003, 27:|233-124I.

42. Jen KL, Djuric Z, DiLaura NM, Buison A, Redd JN, Maranci V, et al: Improvement of metabolism among obese breast cancer survivors in differing weight loss regimens. Obes Res 2004, 1 2:306-312

43. Djuric Z, DiLaura NM, Jenkins I, Darga L, Jen CK, Mood D, et al: Combining weight-loss counseling with the weight watchers plan for obese breast cancer survivors. Obes Res 2002 10:657-665.

44. Nieman DC, Nehlsen-Cannarella SL, Henson DA, Butterworth DE, Fagoaga OR, Warren BJ, Rainwater MK, et al.: Immune response to obesity and moderate weight loss. Int J Obes Relat Metab Disord 1996, 20(4):353-360.

45. Wu AH, Pike MC, Stram DO: Meta-analysis: Dietary fat intake, serum estrogen levels and the risk of breast cancer. J Natl Cancer Inst 1999, 9 1:529-534.

46. Pinto BM, Maruyama NC: Exercise in the rehabilitation of breast cancer survivors. Psycho-Oncology 1999, 8:191-206.

47. Nieman DC, Custer WF, Butterworth DE, Utter AC, Henson DA: Psychological response to exercise training and/or energy restriction in obese women. J Psychosom Res 2000, 48:23-29.

48. Friedenreich CM, Thune I, Brinton LA, Albanes D: Epidemiologic issues related to the association between physical activity and breast cancer. Cancer 1998, 83:600-610.

49. Gammon MD, John EM, Britton JA: Recreational and occupational physical activities and risk of breast cancer. J Natl Cancer Inst 1998, 90:100-I17.

50. Mezzetti M, La Vecchia C, Decarli A, Boyle P, Talamini R, Francesch $S$ : Population attributable risk for breast cancer: diet, nutrition, and physical exercise. I Natl Cancer Inst 1998, 90:389-394.
5I. Moradi T, Adami HO, Bergstrom R, Gridley G, Wolk A, Gerhardsson $M$, et al.: Occupational physical activity and risk for breast cancer in a nationwide cohort study in Sweden. Cancer Causes Control 1999, 10:423-430.

52. Rockhill B, Willett WC, Hunter DJ, Manson JE, Hankinson SE, Colditz GA: A prospective study of recreational physical activity and breast cancer risk. Arch Intern Med 1999, I 59:2290-2296.

53. Verloop J, Rookus MA, van der KK, van Leeuwen FE: Physical activity and breast cancer risk in women aged 20-54 years. J Nat Cancer Inst 2000, 92: I 28-135.

54. Holmes MD, Chen WY, Feskanich D, Kroenke CH, Colditz GA: Physical activity and survival after breast cancer diagnosis. JAMA 2005, 293:2479-2486.

55. Cauley JA, Gutai JP, Kuller LH, LeDonne D, Powell JG: The epidemiology of serum sex hormones in postmenopausal women. Am J Epidemiol 1989, I 29: I | 20- I I3 I.

56. Nelson ME, Meredith CN, Dawson-Hughes B, Evans WJ: Hormone and bone mineral status in endurance-trained and sedentary postmenopausal women. J Clin Endocrinol Metab I988, 66:927-933.

57. Geffken D, Cushman M, Burke G, Polak J, Sakkinen P, Tracy R: Association between physical actvity and markers of inflammation in a health elderly population. Am J Epidemiol 200I, I 53:242-250.

58. Kervinen H, Palosuo T, Manninen V, Tenkanen L, Vaarala O, Manttari $M$ : Joint effects of $\mathrm{C}$-reactive protein and other risk factors on acute coronary events. Am Heart J 200 I, I 4 I:580-585.

59. Smith JK, Dykes R, Douglas JE, Krishnaswamy G, Berk S: Long-term exercise and atherogenic activity of blood mononuclear cells in persons at risk of developing ischemic heart disease. JAMA 1999, 28 I: I 722-1727.

60. Stauffer BL, Hoetzer GL, Smith DT, DeSouza CA: Plasma C-reactive protein is not elevated in physically active postmenopausal women taking hormone replacement therapy. J Appl Physiol 2004, 96: | 43- I 48

6I. Bermudez EA, Rifai N, Buring J, Manson JE, Ridker PM: Interrelationships among circulating interleukin-6, C-reactive protein, and traditional cardiovascular risk factors in women. Arterioscler Thromb Vasc Biol 2002, 22:1668-1673.

62. Visser A, Bouter LM, McQuillan GM, Wener MH, Harris TB: Elevated $C$-reactive protein levels in overweight and obese adults. JAMA 1999, 282:2I3|-2135.

63. Rexrode KM, Pradhan A, Manson JE, Buring JE, Ridker PM: Relationship of total and abdominal obesity with CRP and IL-6 in women. Ann Epidemiol 2003, I 3:674-682

64. Erlinger TP, Platz EA, Rifai N, Helzlsouer $\mathrm{KJ}$ : C-reactive protein and risk of incident colorectal cancer. JAMA 2004, 29 1:585-590.

65. McMillan DC, Elahi MM, Sattar N, Angerson WJ, Johnstone J, McArdle CS: Measurement of the systemic inflammatory response predicts cancer-specific and non-cancer survival in patients with cancer. Nutr Cancer 2001, 41:64-69.

66. Dugue B, Leppanen EA, Teppo AM, Fyhrquist F, Grasbeck R: Effects of psychological stress on plasma interleukins-I beta and 6 , C-reactive protein, tumour necrosis factor alpha, anti-diuretic hormone and serum cortisol. Scand J Clin Lab Invest 1993 , 53:555-56I.

67. Dentino AN, Pieper CF, Rao KMK, Currie MS, Harris T, Blazer DG, et al: Association of interleukin-6 and other biological variables with depression in older people. J Am Geriatr Soc 1999, 47:6-II

68. Maes M, Bosmans E, De jongh R, Kenis G, Vandoolaeghe E, Neels H: Increased serum IL-6 and IL-I receptor antagonist concentrations in major depression and treatment resistant depression. Cytokine 1995, 9:853-858.

69. Lutgendorf SK, Garand L, Buckwalter KC, Reimer TT, Hong S, Lubaroff DM: Life stress, mood disturbance, and elevated interleukin-6 in healthy older women. I Gerontol A Biol Sci Med Sci 1999, 54:M434-9.

70. Silvestri A, Gebara O, Vitale C, Wajngarten M, Leonardo F, Ramires JA, et al.: Increased levels of $\mathbf{C}$-reactive protein after oral hormone replacement therapy may not be related to an increased inflammatory response. Circulation 2003, 107:3165-3169.

7I. Baldwin MK, Courneya KS: Exercise and self-esteem in breast cancer survivors: An application of the exercise and selfesteem model. J Sport Exerc Psychol 1997, 19:347-359. 
72. Courneya KS, Friedenreich CM: Relationship between exercise during treatment and current quality of life among survivors of breast cancer. J Psychosoc Oncol 1997, I 5:35-57.

73. Campbell A, Mutrie N, White F, McGuire F, Kearney N: A pilot study of a supervised group exercise programme as a rehabilitation treatment for women with breast cancer receiving adjuvant treatment. Eur I Oncol Nurs 2005, 9:56-63.

74. Cruess DG, Antoni MH, McGregor BA, Kilbourn KM, Boyers AE, Alferi SM, et al:: Cognitive-behavioral stress management reduces serum cortisol by enhancing benefit finding among women being treated for early stage breast cancer. Psychosom Med 2000, 62:304-308.

75. Davis $\mathrm{H}$ : Effects of biofeedback and cognitive therapy on stress in patients with breast cancer. Psychol Rep 1986 59:967-974.

76. Gruber BL, Hersh SP, Hall NR, Waletzky LR, Kunz JF, Carpenter JK, et al.: Immunological responses of breast cancer patients to behavioral interventions. Biofeedback Self Regul 1993, I 8: I-22.

77. van der Pompe G, Duivenvoorden HJ, Antoni MH, Visser A, Heijnen $\mathrm{C}$ : Effectiveness of a short-term group psychotherapy program on endocrine and immune function in breast cancer patients: an exploratory study. J Psychosom Res 1997, 42:453-466.

78. Peters C, Lotzerich H, Niemeier B, Schule K, Uhlenbruck G: Influence of a moderate exercise training on natural killer cytotoxicity and personality traits in cancer patients. Anticancer Res 1994, 14:1033-1036.

79. Peters C, Lotzerich H, Niemer B, Schule K, Uhlenbruck G: Exercise, cancer and the immune response of monocytes. Anticancer Res 1995, I 5:175-179.

80. Nieman DC, Cook VD, Henson DA, Suttles J, Rejeski WJ, Ribisl PM, et al:: Moderate exercise training and natural killer cell cytotoxic activity in breast cancer patients. Int J Sports Med 1995 1 6:334-337.

8I. Fairey AS, Courneya KS, Field CJ, Bell GJ, Jones LW, Mackay JR: Randomized controlled trial of exercise and blood immune function in postmenopausal breast cancer survivors. J Appl Physiol 2005, 98: I534-I540.

82. Nieman DC, Nehlsen-Cannarella SL, Markoff PA, Balk-Lamberton AJ, Yang $\mathrm{H}$, Chritton DB, et al.: The effects of moderate exercise training on natural killer cells and acute upper respiratory tract infections. Int I Sports Med 1990, I I:467-473.

83. Nieman DC, Henson DA, Gusewitch G, Warren BJ, Dotson RC, Butterworth DE, et al.: Physical activity and immune function in elderly women. Med Sci Sports Exerc 1993, 25:823-83I.

84. Nieman DC: Exercise and resistance to infection. Can J Physiol Pharmacol 1998, 76:573-580.

85. Yamasaki S, Kan N, Harada T, Ichinose Y, Moriguchi Y, Li L, et al.: Relationship between immunological parameters and survival of patients with liver metastases from breast cancer given immuno-chemotherapy. Breast Cancer Res Treat 1993 , 26:55-65.

86. Wiltschke C, Krainer M, Budinsky AC, Berger A, Muller C, Zeillinger $\mathrm{R}$, et al:: Reduced mitogenic stimulation of peripheral blood mononuclear cells as a prognostic parameter for the course of breast cancer: a prospective longitudinal study. $\mathrm{Br} / \mathrm{Cancer}$ 1995, 71: 1292-1296.

87. McTiernan A, Ulrich C, Kumai C, Bean D, Schwartz R, Mahloch J, et al.: Anthropometric and hormone effects of an eight-week exercise-diet intervention in breast cancer patients: results of a pilot study. Cancer Epidemiol Biomarkers Prev 1998, 7:477-48I.

88. Utter AC, Nieman DC, Shannonhouse EM, Butterworth DE, Nieman $\mathrm{CN}$ : Influence of diet and/or exercise on body composition and cardiorespiratory fitness in obese women. Int J Sport Nutr 1998, 8:213-222

89. Treasure T, MacRae KD: Minimisation: the platinum standard for trials? Brit Med J 1998, 3 17:362-363.

90. Wadden TA, Steen SN, Wingate BJ, Foster GD: Psychosocial consequences of weight reduction: how much weight loss is enough? Am J Clin Nutr 1996, 63:46IS-465S.

91. Daley AJ, Mutrie N, Crank H, Coleman R, Saxton J: Exercise therapy in women who have had breast cancer: design of the Sheffield women's exercise and well-being project. Health Educ Res 2004, 19:686-697.

92. Prochaska JO, Norcross JC, Fowler J, Follick M, Abrams DB: Attendance and outcomes in a work-site weight control program:
Processes and stages of change as process and predictor variables. Addictive Behav 1992, 1 7:35-45.

93. Borg G: Perceived exertion as an indicator of somatic stress. Scand I Rehabil Med 1970, 2:92-98.

94. Biddle SJH, Fox K, Boutcher SH, Faulkner G: The way forward for physical activity and the promotion of psychological wellbeing. In Physical Activity and Psychological Well-being Edited by: Biddle $\mathrm{SJH}$, Fox K, Boutcher SH, Faulkner G. London: Routledge; 2000:154-168.

95. Cohen S, Kamarck T, Mermelsstein R: A global measure of perceived stress. J Health Soc Behav 1983, 24:386-396.

96. Beck AT, Steer R, Brown GK: Beck Depression Inventory (BDI-II) London: The Psychological Corporation; 1996.

97. Ebbeling CB, Ward A, Puleo EM, Widrick J, Rippe JM: Development of a single-stage submaximal treadmill walking test. Med $\mathrm{Sci}$ Sports Exerc 1991, 23:966-973.

98. Kolden GG, Strauman TJ, Ward A, Kuta J, Woods TE, Schneider KL, et al:: A pilot study of group exercise training (GET) for women with primary breast cancer: feasibility and health benefits. Psycho-Oncology 2002, I I:447-456.

99. Cella DF, Tulsky DS, Gray G, Serafin B, Linn E, Bonomi A, et al.: The functional assessment of cancer therapy scale: Development and validation of the general measure. J Clin Oncol 1993, I I :570-579.

100. Sallis JF, Haskell WL, Wood PD, Fortmann SP, Rogers T, Blair SN, et al.: Physical activity assessment methodology in the Five-City Project. Am J Epidemiol 1985, I 2 1:91-106.

I0I. Chang L, Gusewitch GA, Chritton DB, Folz JC, Lebeck LK, NehlsenCannarella SL: Rapid flow cytometric assay for the assessment of natural killer cell activity. J Immunol Methods 1993, I 66:45-54.

102. Mannering SI, Morris JS, Jensen KP, Purcell AW, Honeyman MC, van Endert PM, et al.: A sensitive method for detecting proliferation of rare autoantigen-specific human $\mathbf{T}$ cells. J Immunol Methods 2003, 283:173-183.

\section{Pre-publication history}

The pre-publication history for this paper can be accessed here:

http://www.biomedcentral.com/1471-2407/6/35/prepub
Publish with Bio Med Central and every scientist can read your work free of charge

"BioMed Central will be the most significant development for disseminating the results of biomedical research in our lifetime. "

Sir Paul Nurse, Cancer Research UK

Your research papers will be:

- available free of charge to the entire biomedical community

- peer reviewed and published immediately upon acceptance

- cited in PubMed and archived on PubMed Central

- yours - you keep the copyright

Submit your manuscript here:

http://www.biomedcentral.com/info/publishing_adv.asp
BiolMedcentral 